\title{
New Insights into the Effect of Origanum Extracts on the Gene Expression Profiles of Multidrug-Resistant Isolates of Pseudomonas aeruginosa Retrieved from Oreochromis niloticus
}

\author{
Ali Wahdan ${ }^{1, *}\left(\mathbb{D}\right.$, Amr Fadel $^{2}$, Mahmoud Mabrok ${ }^{3}$ \\ ${ }^{1}$ Suez Canal University, Department of Bacteriology, Immunology and Mycology, Faculty of Veterinary Medicine, \\ Ismailia 41522, Egypt. \\ ${ }^{2}$ National Institute of Oceanography and Fisheries, Aquaculture Division, Laboratory of Fish Diseases, Alexandria, \\ 21556, Egypt. \\ ${ }^{3}$ Suez Canal University, Department of Fish Diseases and Management, Faculty of Veterinary Medicine, Ismailia 41522, \\ Egypt.
}

\section{Article History}

Received 19 July 2019

Accepted 10 December 2019

First Online 16 December 2019

\section{Corresponding Author}

Tel.: +201008705642

E-mail:dr_aly_w@yahoo.com

\section{Keywords}

Pseudomonas aeruginosa

Multidrug resistance

Gene expression

Origanum extracts

Oreochromis niloticus.

\begin{abstract}
Pseudomoniasis has become a serious threat not only as a disease but also for the ensuing emergence of antibiotic-resistant bacteria. Thus, a total of 180 Oreochromis niloticus and water samples were collected from three intensive farms located in Ismailia Governorate for physicochemical and biological analysis. All retrieved isolates were tested for the presence of the $P$. aeruginosa oprL gene and for their sensitivity to commercial antimicrobial agents. Isolates showing multidrug resistance (MDR) were examined for the presence of exoS, toxA, mexA, and mexB. The sensitivity of those isolates and their virulence genes expression profiles were evaluated following treatment with Origanum marjoram and Origanum vulgare. Analyzed water samples showed a high load of total and fecal coliforms and indicated faecal contamination. The prevalence of $P$. aeruginosa in examined fish was $6.11 \%$. All isolates harboured the oprL gene and showed different sensitivity to the antimicrobial agents. Only four isolates showed MDR and harboured all genes of interest. Both herbal extracts were effective and reduced the expression levels of exoS and toxA genes, even at subinhibitory concentrations. Despite the pathogenicity and antibiotic-resistance patterns of $P$. aeruginosa, it can be controlled by herbal medication, and thus encourages their use as antibiotic surrogates in aquaculture.
\end{abstract}

\section{Introduction}

Oreochromis niloticus is considered one of the most cultured and highly consumed species in Egypt and worldwide due to its economical price, palatability, and high protein, vitamin, and mineral contents for humans (Abdullahi, Abolude, \& Ega, 2001; FAO, 2018). Like other aquatic creatures, tilapia spontaneously exposed to several infectious diseases that represent one of the obstacles facing the fish farming sector (Senapin, Shyam, Meemetta, Rattanarojpong, \& Dong, 2018).

Recently, Somsiri and Soontornvit (2002) and Fadel, Mabrok and Aly (2018) briefly elucidated the pathogenicity and economic losses induced by
Pseudomonas spp. among different aquatic animals. Pseudomoniasis mostly characterized by abdominal swelling, detached scales, diffused petechial hemorrhage, and exophthalmia (Kumaran, Deivasigamani, Alagappan, Sakthivel \& Prasad, 2010; Omar, Moustafa, Abo-Remela \& Zayed, 2017). Moreover, $P$. aeruginosa contributes numerous membrane and extracellular virulence factors that are involved in pathogenicity and disease induction (Mitov, Strateva \& Markova, 2010; Khattab, Nour \& EISheshtawy, 2015).

The evolution of antibiotic resistance recently had a global concern (Castanon, 2007). The frequent and haphazard use of antibiotics has led to the emergence 
of commensal resistant strains that have been transferred to zoonotic bacteria of public health concern (Benie, Nathalie \& Adjéhi, 2017). Among these bacteria, $P$. aeruginosa conveys multi-resistance patterns to many antibiotics, which may be acquired (plasmids, transposons) or natural (Sharma \& Srivastava, 2016). Consequently, there is an imperative need to find other alternatives to identify other suitable antimicrobial alternatives such as medicinal herbal extracts and multiple probiotics mixture to improve the growth performance and enhance the immune response of Nile tilapia Oreochromis niloticus (Hwang et al., 2019). Herbal medication is currently flourishing and represents a new pharmacological trend in disease control (Bagamboula, Uyttendaele \& Debevere, 2004; Ismail, Wahdan, Yusuf, Metwally \& Mabrok, 2019). The mode of action of herbal medicines is mainly via altering the biosynthesis and permeability of the bacterial cell wall and controlling efflux activities (Wienkötter, Begrow, Kinzinger, Schierstedt \& Verspohl, 2007; Schmidt et al., 2012; Handzlik, Matys \& KiećKononowicz, 2013) .

Origanum majorana L. (marjoram) and Origanum vulgare essential oils have potential antimicrobial properties and are used extensively in industrial and field applications (Busatta et al., 2008). Carvacrol and thymol are the main active ingredients, and both components have antibacterial properties (Lambert, Skandamis, Coote \& Nychas, 2001). Although a few investigations have affirmed the antimicrobial nature of oregano essential oils against fish pathogens, no studies have discussed the role of these compounds in regulating the expression profiles of some bacterial virulence genes. Therefore, the present study aimed to investigate the correlation between water parameters and the incidence of $P$. aeruginosa infections among some intensive tilapia farms, identify the most multidrug-resistant (MDR) isolates, and evaluate their sensitivity to oregano essential oils in terms of the antibacterial activity, minimum inhibitory concentration (MIC), and minimum bactericidal concentration (MBC) to find an alternative and innovative solution to overcome the serious problem of antibiotic resistance.

\section{Materials and Methods}

\section{Water Sampling}

Representative water samples were collected randomly during the summer of 2017 (May-July) from three earthen pond farms located in Ismailia Governorate, Egypt and implemented an intensive rearing system. Our team collected $200 \mathrm{ml}$ water samples in different labelled sterile glasses with stoppers and transferred them in insulated coolers to the laboratory of Fish Diseases and Management Department, Faculty of Vet. Med. Suez Canal University for further analysis (2-3 h upon arrival). Physical, chemical, and microbial analyses were performed following the standard methods for the examination of water and wastewater, the American Public Health Association (APHA, 2005).

\section{Fish Sampling}

One hundred and eighty freshly caught samples of O. niloticus weighing $90-280 \pm 13$ g were collected randomly from the same different localities $(60$ fish/farm) and transferred immediately in iceboxes to the laboratory. Samples were investigated for behavioural abnormalities and pathological lesions according to Austin and Austin (2012).

\section{Bacteriological Examination and Molecular Confirmation of Pseudomonas spp.}

Fresh specimens from the skin lesions, liver, kidneys, and spleen of examined fish were inoculated on Pseudomonas base agar and/or nutrient agar and incubated for $24-48 \mathrm{~h}$ at $37{ }^{\circ} \mathrm{C}$. The suspected colonies were purified for morphological and biochemical identifications according to Mac Faddin (1985). To ensure that the isolates belonged to the genus Pseudomonas, one set of primers targeting the oprL gene was selected according to Matthijs et al. (2013). The list of oligonucleotide sequences used in the current study is provided in Table 1 . The genomic DNA of 11 representative bacterial isolates was extracted using the QIAamp DNA Mini Kit (Invitrogen, USA) following the manufacturer's protocol for genomic DNA extraction from bacterial cells. Genomic DNA samples with purification ratios of $1.8-2.1$ at $260 / 280 \mathrm{~nm}$ were quantified using a Nanodrop (Nanodrop 1000, Thermo Scientific, UK), adjusted to $100 \mathrm{ng} \mu \mathrm{l}^{-1}$, and kept frozen at $-20^{\circ} \mathrm{C}$ until use as templates for PCR.

PCR mixtures $(25 \mu \mathrm{l})$ were amplified in a T Gradient Thermocycler (Biometra, Jena, Germany) using a commercial Green Master Mix Kit (NZYtech). The samples were subjected to initial denaturation at $94^{\circ} \mathrm{C}$ for $2 \mathrm{~min}$, followed by 30 cycles of denaturing at $94^{\circ} \mathrm{C}$ for $30 \mathrm{sec}$, annealing at $50^{\circ} \mathrm{C}$ for $45 \mathrm{sec}$, and extension and signal acquisition at $72^{\circ} \mathrm{C}$ for $30 \mathrm{sec}$. Amplified products were detected by horizontal $1.5 \%(\mathrm{w} / \mathrm{v})$ agarose gel electrophoresis (Applichem, Germany, GmbH) for 30 $\min$ at $100 \mathrm{~V}$ in $1 \mathrm{x}$ TBE (0.04 M Tris, $0.0001 \mathrm{M}$ EDTA, pH 8.0) electrophoresis buffer, photographed under UV light and computer digitized (Gel Doc 100, Bio-Rad).

\section{Antibiotic Susceptibility of $\boldsymbol{P}$. aeruginosa Isolates}

For inoculum preparation, each bacterial isolate was subcultured in tryptic soy broth (TSB) (MHB; Difco) for $24 \mathrm{~h}$ at $37^{\circ} \mathrm{C}$. Subsequently, the bacteria were adjusted to a final concentration of $10^{7} \mathrm{CFU} \mathrm{m} \mathrm{^{-1 }}$ using the McFarland reaction and were confirmed by the plate counting technique. The susceptibility of those isolates to various commercial antimicrobial agents (Oxoid) (florfenicol $(30 \mu \mathrm{g})$, amoxicillin $(25 \mu \mathrm{g})$, penicillin $(10 \mu \mathrm{g})$, 
Table. 1. Oligonucleotides sequences (primers) used in the current study for molecular analysis and gene expression

\begin{tabular}{|c|c|c|c|c|}
\hline Primer & & Sequence $\left(5^{\prime}-3^{\prime}\right)$ & Product length & Reference \\
\hline \multirow[t]{2}{*}{ oprL } & $\mathrm{F}$ & ATGGAAATGCTGAAATTCGGC & $504 \mathrm{bp}$ & (Matthijs et al., 2013) \\
\hline & $\mathrm{R}$ & CTTCTTCAGCTCGACGCGACG & & \\
\hline \multirow[t]{2}{*}{ exos } & $\mathrm{F}$ & CTTGAAGGGACTCGACAAGG & $504 \mathrm{bp}$ & (Strateva, 2008) \\
\hline & $\mathrm{R}$ & TTCAGGTCCGCGTAGTGAAT & & \\
\hline \multirow[t]{2}{*}{ toxA } & $\mathrm{F}$ & GACAACGCCCTCAGCATCACCAGC & 396 bp & (Matar et al., 2002) \\
\hline & $\mathrm{R}$ & CGCTGGCCCATTCGCTCCAGCGCT & & \\
\hline \multirow[t]{2}{*}{$\operatorname{mexA}$} & $\mathrm{F}$ & CGACCAGGCCGTGAGCAAGCAGC & 316 bp & (Dumas et al., 2006) \\
\hline & $\mathrm{R}$ & GGAGACCTTCGCCGCGTTGTCGC & & \\
\hline \multirow[t]{2}{*}{$\operatorname{mexB}$} & $\mathrm{F}$ & GTCTTCGGCTCGCAGTACTC & $244 \mathrm{bp}$ & (Xavier et al., 2010) \\
\hline & $\mathrm{R}$ & AACCGTCGGGATTGACCTTG & & \\
\hline
\end{tabular}

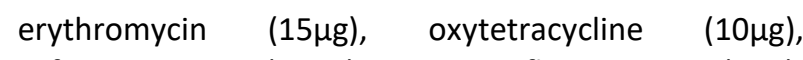
ceftriaxone $\quad(30 \mu \mathrm{g})$, ciprofloxacin $(5 \mu \mathrm{g})$, sulfamethoxazole/trimethoprim $(25 \mu \mathrm{g})$, gentamicin (10 $\mu \mathrm{g})$ and streptomycin $(10 \mu \mathrm{g}))$ were then evaluated in triplicate using the disc diffusion method (BertrandHarb, Ivanova, Dalgalarrondo \& Haertllé, 2003). The inhibition zone diameters were estimated according to Jorgensen, Hindler, Reller and Weinstein (2007). Isolates that showed high resistance to more than three antimicrobial agents were defined as MDR isolates and were selected for further molecular studies.

\section{Molecular Detection of Virulence and Antibiotic Resistance Genes Among MDR Isolates}

To verify the virulence of $P$. aeruginosa MDR strains, specific primers targeting the toxA and exos virulence genes were selected according to Matar, Ramlawi, Hijazi, Khneisser and Abdelnoor (2002) and Strateva (2008), respectively. Furthermore, the antibiotic extrusion machinery in Pseudomonas isolates and its role in antibiotic resistance was identified using two sets of primers targeting mexA and mexB according to Dumas, Van Delden, Perron and Köhler (2006) and Xavier, Picão, Girardello, Fehlberg and Gales (2010). The list of oligonucleotide sequences used is provided in Table 1. Samples were subjected to initial denaturation at $94^{\circ} \mathrm{C}$ for $5-10 \mathrm{~min}$, followed by 30 cycles of denaturing at $94^{\circ} \mathrm{C}$ for $30 \mathrm{sec}$, annealing at $50-55^{\circ} \mathrm{C}$ for $30-45 \mathrm{sec}$, and extension and signal acquisition at $72^{\circ} \mathrm{C}$ for $30 \mathrm{sec}$. Amplified products were detected as described above.

\section{Antibacterial Activity, Minimum Inhibitory Concentration (MIC), and Minimum Bactericidal Concentration (MBC) of the Evaluated Herbal Essential Oils}

Two plant derivative essential oils $(O$. vulgare and O. marjoram) were purchased from Sigma Aldrich and further diluted in dimethyl sulfoxide (DMSO) to form a stock solution of $512 \mu \mathrm{g} \mathrm{ml}^{-1}$. Subsequently, serial double-fold dilutions of the stock solutions were performed to reach final oil concentrations ranging from 512 to $2 \mu \mathrm{g} \mathrm{ml}^{-1}$. The antimicrobial activity of each derivative against the four selected MDR $P$. aeruginosa isolates was performed in triplicate using the disc diffusion method (Bertrand-Harb et al., 2003). To determine the MIC and MBC, the broth dilution method was used following the instruction protocols of the Clinical and Laboratory Standards Institute (CLSI, 2008).

\section{RNA Isolation and Real-Time Quantitative PCR (RT- qPCR)}

The effect of three sub-inhibitory concentrations (SICS) of $O$. vulgare and $O$. marjoram essential oil extracts on $P$. aeruginosa virulence gene expression (exos and toxA) was investigated using RT-qPCR. Pseudomonas aeruginosa (P. 9) was selected as a representative sample for MDR isolates since it exhibited high susceptibility to both evaluated essential oils. Briefly, the strain was cultured separately either with the respective SICs of the evaluated compounds in TSB or with TSB without treatment (control) at $37^{\circ} \mathrm{C}$ to mid-log phase, and the total RNA was extracted using TRIzol Reagent (Sigma) following the manufacturer's specifications. Subsequently, each sample was treated with DNase I (Promega, Madison, USA) to eliminate DNA contamination, and first-strand cDNA was synthesized with the NZY First-Strand cDNA Synthesis Kit (NZYTech) following the manufacturer's protocols. The quantity of RNA was measured at $260 \mathrm{~nm}$ using a NanoDrop 1000 Spectrophotometer (Thermo Scientific, UK), while the quality was assessed by measuring the ratio of the absorbance at $260 \mathrm{~nm} / 280 \mathrm{~nm}$ and by electrophoresis on a denaturing agarose gel. A ratio of 1.8-2.1 (260 $\mathrm{nm} / 280 \mathrm{~nm}$ ) or $2: 1$ ratio (28S:18S) was generally accepted and is considered a good indicator for RNA integrity. The amplifications were then performed in a Mastercycler RealPlex4 PCR System (Eppendorf) using 1 $\mu \mathrm{L}$ of diluted CDNA template (1:5 dilution) mixed with 10 $\mu \mathrm{L}$ of IQ SYBR Green Supermix (Bio-Rad) and $0.4 \mu \mathrm{L}$ (10 $\mu \mathrm{M}$ ) of each specific primer in a final volume of $20 \mu \mathrm{L}$. The list of oligonucleotide sequences is provided in Table 1 . The primer efficiency was analyzsed in serial five-fold dilutions of cDNA by calculating the slope of the regression line of the cycle thresholds $(\mathrm{Ct})$ versus the relative concentration of cDNA (Livak \& Schmittgen, 2001). The standard cycling conditions were $94{ }^{\circ} \mathrm{C}$ for 5 min followed by 40 cycles of $94{ }^{\circ} \mathrm{C}$ for $30 \mathrm{sec}, 50-60{ }^{\circ} \mathrm{C}$ for $30-45 \mathrm{sec}$, and $72{ }^{\circ} \mathrm{C}$ for $30-45 \mathrm{sec}$. All reactions were performed as technical triplicates. The transcript level of 
each candidate gene was normalized to the expression of the oprL gene (housekeeping gene), as this gene is constitutively and constantly expressed independently of treatments (Alqarni, Colley, Klebensberger, McDougald, \& Rice, 2016). Data are presented as fold change units calculated by dividing the normalized expression values of each treated sample by the normalized expression values of the control (unstimulated samples). Data below one fold were considered negative (downregulated) and thus were presented using the log2 function.

\section{Statistical Analyses}

All results are presented as the means \pm standard deviation (SD). Data normality was evaluated using a Shapiro-Wilk test, while the homogeneity of variance was verified using Levene's test. Data were analyzed by one-way ANOVA, followed by Tukey's post hoc test through paired-comparisons to detect the differences between treatments. All statistical analyses were performed using the computer package statistical 12 for Windows. The level of significance used was $P \leq 0.05$ for all statistical tests.

\section{Results}

\section{Water Analysis}

Throughout the study, some of the physicochemical parameters and total microbial load were recorded (Table 2). In all farms, the $\mathrm{pH}$ values were between 7.5 and 9.0, whereas the unionized ammonia values $\mathrm{NH}_{3}$ were between 0.39 and $0.52 \mathrm{mg} \mathrm{l}^{-1}$. Moreover, the range of values for all ponds were 3.5-4.0 $\mathrm{mg} \mathrm{l}^{-1}$ for dissolved oxygen, $29-31^{\circ} \mathrm{C}, 140-148 \mathrm{mg} \mathrm{CaCO}_{3}$ $\mathrm{I}^{-1}$ for alkalinity, 23-30 NTU for turbidity and 152-158 mg $\mathrm{CaCO}_{3} \mathrm{I}^{-1}$ for total hardness. Regarding the microbial water load, the values of the total viable bacterial count (CFU ml ${ }^{-1}$ ) were $5.7 \times 10^{4}, 4.7 \times 10^{4}$, and $5.2 \times 10^{4}$ for farms $A, B$ and $C$, respectively. The total coliform (TC) values were between 32000 and $35000100 \mathrm{ml}^{-1}$, whereas the faecal coliform (FC) count ranged from 2100 to 2250100 $\mathrm{ml}^{-1}$.

\section{Bacteriological Findings}

The fish naturally infected with $P$. aeruginosa mostly displayed lethargy, reduced appetite, corneal opacity, skin discoloration, pale gills, hemorrhagic ulcers, and eroded fins. Other diseased fish showed bilateral exophthalmia. The results of the bacteriological analysis revealed that 11 out of 180 fish samples were bacteriologically positive with $P$. aeruginosa, with a total prevalence of $6.11 \%$. The prevalence of $P$. aeruginosa were $8.3,6.66$, and $3.33 \%$, for farms $A, B$, and $C$, respectively. Morphologically, the pure cultures of $P$. aeruginosa had characteristic blue-green colonies on Pseudomonas agar, whereas on nutrient agar, they appeared as large irregular greenish-blue colonies with a characteristic grape-like odour. Biochemically, all isolates reacted positively to catalase, oxidase, nitrite reduction, ornithine decarboxylase, and arginine dihydrolase, while they were negative for the Gram stain, indole, Vogues-Proskauer (VP), and methyl red. Collectively, 34 isolates of $P$. aeruginosa were recovered from skin lesions and internal organs. The highest prevalence was recorded in the skin lesions and liver (32.35\%, for each), followed by the kidney $(23.53 \%)$ and spleen (11.76\%), as shown in Table 3.

\section{Genetic Typing of $\boldsymbol{P}$. aeruginosa}

All retrieved strains were positive for oprL, a conserved gene of $P$. aeruginosa with a specific amplicon size of 504 bp, as shown in Figure 1.

\section{Antibiotic Susceptibility Test}

The retrieved isolates showed different susceptibility patterns to several commercial

Table. 2. Physicochemical water parameters and the microbial load of three intensive earthen pond farms of $O$. niloticus located in Ismailia Governorate during the summer of 2017

\begin{tabular}{|c|c|c|c|c|c|}
\hline \multirow[t]{2}{*}{ Parameter (unit) } & \multicolumn{3}{|c|}{ Farm } & \multicolumn{2}{|c|}{ Descriptive Statistics } \\
\hline & A & $\mathrm{B}$ & $\mathrm{C}$ & Mean $\pm S D$ & Range \\
\hline Turbidity (NTU) & 23 & 25 & 30 & $26 \pm 3.60$ & $23-30$ \\
\hline $\mathrm{pH}$ & 7.5 & 8.4 & 9.0 & $8.3 \pm 0.75$ & $7.5-9.0$ \\
\hline Temperature & 30 & 29 & 31 & $30 \pm 1.0$ & 29-31 \\
\hline Conductivity $\left(\mu \mathrm{S} \mathrm{cm}^{-1}\right)$ & 571 & 63 & 557 & $563.67 \pm 7.02$ & $557-571$ \\
\hline TDS (mg l-1) & 342.6 & 337.8 & 334.2 & $338.2 \pm 4.2$ & $334-342$ \\
\hline Alkalinity $\left(\mathrm{mg} \mathrm{CaCO}_{3} \mathrm{l}^{-1}\right)$ & 148 & 140 & 146 & $144.67 \pm 4.2$ & $140-148$ \\
\hline Total Hardness ( $\left.\mathrm{mg} \mathrm{CaCO}_{3}\right|^{-1}$ ) & 158 & 154 & 152 & $154.67 \pm 3.05$ & $152-158$ \\
\hline $\mathrm{DO}\left(\mathrm{mg} \mathrm{l}^{-1}\right)$ & 3.5 & 3.8 & 4.0 & $3.76 \pm 0.25$ & $3.5-4.0$ \\
\hline $\mathrm{NH}_{3}\left(\mathrm{mg} \mathrm{l}^{-1}\right)$ & 0.52 & 0.48 & 0.39 & $0.46 \pm 0.067$ & $0.39-0.52$ \\
\hline TBC CFU ml-1 & $5.7 \times 10^{4}$ & $4.7 \times 10^{4}$ & $5.2 \times 10^{4}$ & $5.2 \times 10^{4} \pm 5 \times 10^{3}$ & $4.7 \times 10^{4}-5.7 \times 10^{4}$ \\
\hline TC $100 \mathrm{ml}^{-1}$ & 32000 & 35000 & 34000 & $33600 \pm 1520$ & $32000-35000$ \\
\hline FC $100 \mathrm{ml}^{-1}$ & 2250 & 2150 & 2100 & $2166.6 \pm 76.4$ & $2100-2250$ \\
\hline
\end{tabular}

Data are expressed as the means \pm SD. TDS= Total dissolved solid, DO= Dissolved oxygen, $T B C=$ Total bacterial count, $T C=$ Total coliform, FC= Faecal coliform. 
Table. 3. Prevalence of $P$. aeruginosa in examined tissues of naturally infected Nile tilapia (O. niloticus)

\begin{tabular}{|c|c|c|c|c|c|c|c|c|}
\hline \multirow[t]{3}{*}{ Total no. of isolates } & \multicolumn{8}{|c|}{ Prevalence of $P$. aeruginosa in examined tissues } \\
\hline & \multicolumn{3}{|c|}{ Skin lesions } & Liver & \multicolumn{2}{|c|}{ Kidney } & \multicolumn{2}{|c|}{ Spleen } \\
\hline & No. & $\%$ & No. & $\%$ & No. & $\%$ & No. & $\%$ \\
\hline 34 & 11 & 32.35 & 11 & 32.35 & 8 & 23.53 & 4 & 11.76 \\
\hline
\end{tabular}

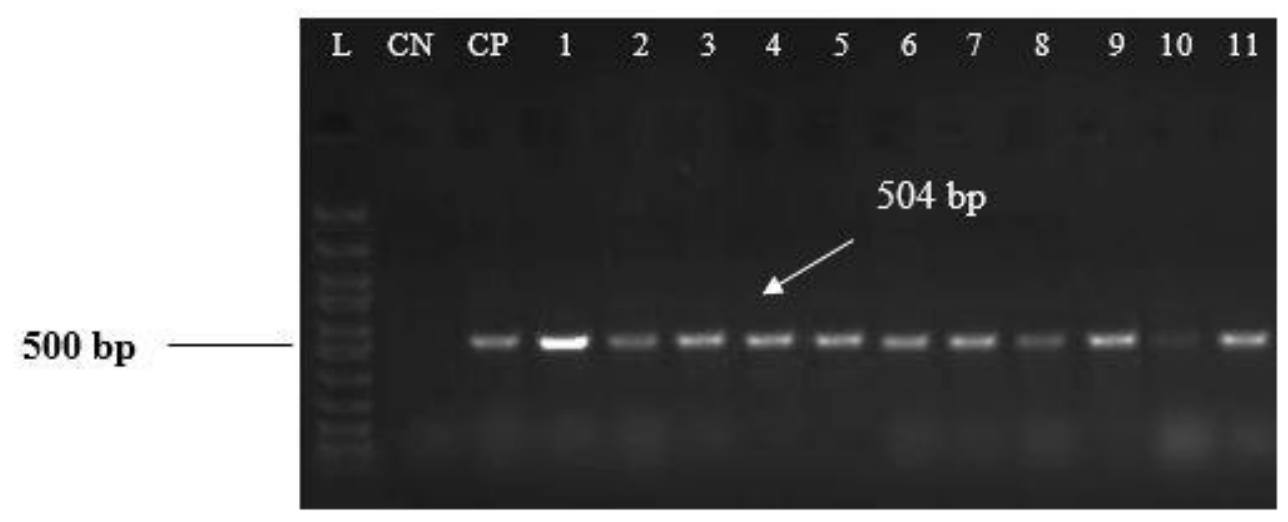

Figure 1. Electrophoretic pattern of primers targeting oprL. Lanes marked L refer to a $100 \mathrm{bp}$ ladder (Thermo Scientific). CP is the positive control ( $P$. aeruginosa ATCC 27853), CN is the negative control (DNA free template), and lanes 1-11 show the specific DNA product of approximately 504 base pairs (bp) amplified from all retrieved isolates.

antimicrobial agents (Table 4). The evaluated strains were entirely sensitive to streptomycin (100\%), highly sensitive to gentamycin, oxytetracycline, ciprofloxacin, and sulfamethoxazole/trimethoprim $(90.9,90.9,90.9$, and $81.8 \%$, respectively) and highly resistant to florfenicol and amoxicillin $(81.8$ and 63.6\%, respectively). Erythromycin did not display any antimicrobial activity with a $100 \%$ resistance pattern. Surprisingly, 4 out of 11 evaluated strains (named P2, P5, P8, and P9) showed resistance to more than three antimicrobial agents and were defined as MDR strains.

\section{Genotyping of Some Virulence and Antibiotic Resistance Genes Among $P$. aeruginosa MDR Strains}

The presence of some virulence and antibiotic resistance genes among $P$. aeruginosa MDR strains was investigated. The results showed that all evaluated strains harboured exoS, tox $\mathrm{A}, \operatorname{mex} \mathrm{A}$, and mexB, with specific amplicons of 504, 396, 316, and 244 bp, respectively (Figures $2-5$ ).

\section{Bactericidal Activity, MIC and MBC of Herbal Essential Oil Extracts}

As shown in Tables 5 and 6, all the tested isolates showed different patterns of sensitivity represented by wide zones of inhibition $(\mathrm{mm})$ against both essential oil extracts, where increased bactericidal activity against $P$. aeruginosa isolates was achieved following treatment with $O$. marjoram, with wide inhibitory zones ranging from 16 to $33 \mathrm{~mm}$ in diameter. For O. vulgare, the bactericidal activity was diminished, and the inhibitory zones decreased to $15-29 \mathrm{~mm}$. Simultaneously, the concentrations of both herbal oils that prevented visible growth or killed such bacteria were recorded (Tables 5 , 6). Accordingly, the MIC of $O$. marjoram essential oil was $8 \mu \mathrm{g} \mathrm{ml}^{-1}$, and the $\mathrm{MBC}$ ranged from 16 to $128 \mathrm{\mu g} \mathrm{ml}^{-1}$. In the case of $O$. vulgare, the MIC was $16 \mu \mathrm{g} \mathrm{ml}^{-1}$, and the $\mathrm{MBC}$ ranged from 32 to $128 \mu \mathrm{g} \mathrm{ml}^{-1}$.

\section{Regulatory Effect of Herbal Essential Oil Extracts on the Expression Profile of Some Virulence Genes of $\boldsymbol{P}$. aeruginosa MDR Isolates}

The expression levels of the exoS and toxA virulence genes following treatment with three sub inhibitory concentrations (SICS) of $O$. marjoram and $O$. vulgare essential oil extracts were recorded (Figure 6A, B). These expression levels were downregulated by the used herbal oils at their respective SICS $(P<0.05)$ compared to those in the control. All encoding genes were downregulated in proportion to the herbal oil concentrations. For instance, $O$. marjoram and $O$. vulgare at high SICs reduced the expression level of the exoS gene up to 13- and 5-fold and the expression level of the toxA gene up to 10 - and 3-fold, respectively. Similarly, at low SICs, the herbal extracts downregulated the expression profiles of both genes up to 5-and 1-fold, respectively.

\section{Discussion}

In the current study, all the measured physiochemical parameters values including; $\mathrm{pH}$, total hardness, total alkalinity, and TDS were fallen within the recommended standard for fish culture. However, the DO values were lower than the target water quality 
Table. 4. Antibiotic susceptibility of eleven $P$. aeruginosa isolates retrieved from naturally infected Nile tilapia (O. niloticus)

\begin{tabular}{|c|c|c|c|c|c|c|c|c|c|c|}
\hline \multirow{2}{*}{$\begin{array}{l}\text { Isolate } \\
\text { no. }\end{array}$} & \multicolumn{10}{|c|}{ Antimicrobial agents } \\
\hline & $\mathrm{F}^{+}$ & $\mathrm{AMO}^{\ddagger}$ & $\mathrm{P} \S$ & $E^{\text {I }}$ & O१ศा & CROๆาศๆ & CIP\# & SXT"\# & $\mathrm{G}^{*}$ & $S^{¥ ¥}$ \\
\hline 1 & $\mathrm{~S}$ & $\mathrm{R}$ & $S$ & $\mathrm{R}$ & $\mathrm{S}$ & $\mathrm{S}$ & $\mathrm{S}$ & $\mathrm{S}$ & $\mathrm{S}$ & $\mathrm{S}$ \\
\hline 2 & $\mathrm{R}$ & $\mathrm{R}$ & $\mathrm{R}$ & $\mathrm{R}$ & $S$ & $\mathrm{R}$ & $S$ & $\mathrm{R}$ & S & $S$ \\
\hline 3 & $\mathrm{R}$ & $S$ & $S$ & $\mathrm{R}$ & S & $S$ & S & $S$ & S & $S$ \\
\hline 4 & $\mathrm{R}$ & $S$ & $S$ & $\mathrm{R}$ & S & $S$ & S & $S$ & S & $S$ \\
\hline 5 & $\mathrm{R}$ & $\mathrm{R}$ & $\mathrm{R}$ & $\mathrm{R}$ & $\mathrm{R}$ & $\mathrm{R}$ & $\mathrm{R}$ & $S$ & S & $\mathrm{S}$ \\
\hline 6 & $\mathrm{R}$ & $\mathrm{R}$ & $\mathrm{S}$ & $\mathrm{R}$ & $S$ & $\mathrm{~S}$ & $S$ & $S$ & $S$ & $S$ \\
\hline 7 & S & $\mathrm{S}$ & S & $\mathrm{R}$ & $S$ & $S$ & $S$ & $S$ & S & $S$ \\
\hline 8 & $\mathrm{R}$ & $\mathrm{R}$ & $\mathrm{R}$ & $\mathrm{R}$ & $S$ & $\mathrm{R}$ & $S$ & $\mathrm{R}$ & $R$ & $S$ \\
\hline 9 & $\mathrm{R}$ & $\mathrm{R}$ & $\mathrm{R}$ & $R$ & $S$ & $\mathrm{R}$ & $S$ & $S$ & $S$ & $S$ \\
\hline 10 & $\mathrm{R}$ & $S$ & $\mathrm{~S}$ & $\mathrm{R}$ & $S$ & $\mathrm{~S}$ & $S$ & $S$ & $S$ & $S$ \\
\hline 11 & $\mathrm{R}$ & $\mathrm{R}$ & $\mathrm{S}$ & $\mathrm{R}$ & $\mathrm{S}$ & $S$ & $\mathrm{~S}$ & $S$ & $\mathrm{~S}$ & $\mathrm{~S}$ \\
\hline
\end{tabular}

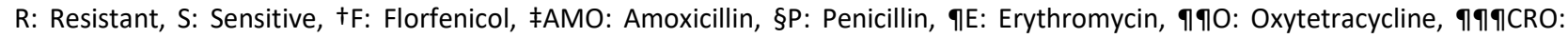
Ceftriaxone, \#CIP: Ciprofloxacin, \#\#SXT: Sulfamethoxazole/Trimethoprim, ¥G: Gentamycin, ¥¥S: Streptomycin.

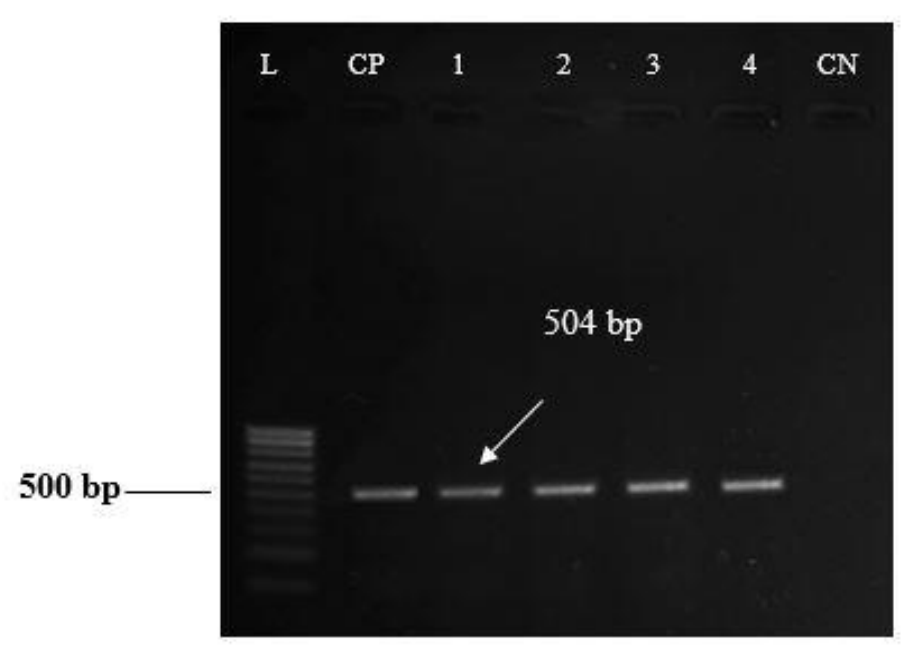

Figure 2. Electrophoretic pattern of primers targeting the exoS gene. $L$ refers to the $100 \mathrm{bp}$ ladder (Thermo Scientific). $C P$ is the positive control ( $P$. aeruginosa ATCC 27853), CN is the negative control (DNA free template), and lanes 1-4 show the specific DNA product of approximately 504 base pairs (bp) amplified from all retrieved multi-drug resistant (MDR) isolates.

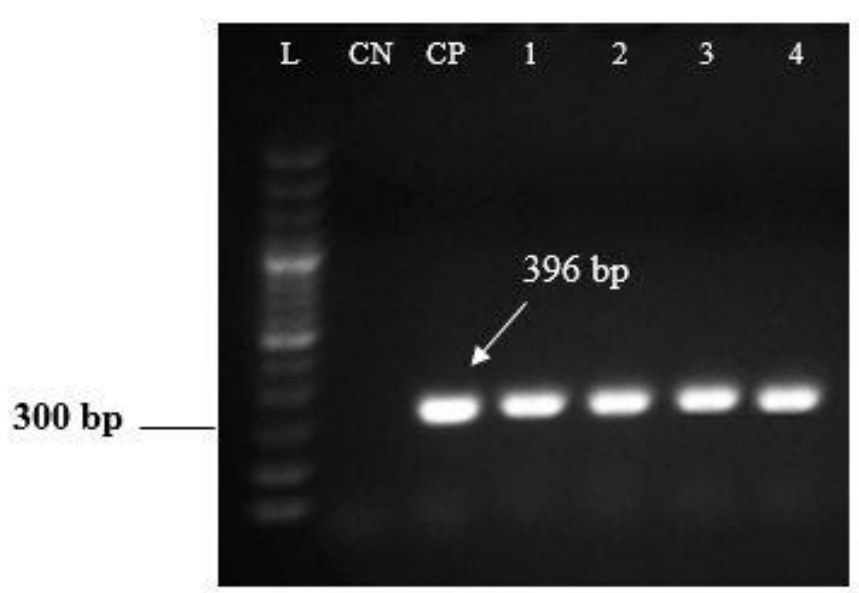

Figure 3. Electrophoretic pattern of primers targeting the toxA gene. $L$ refers to the $100 \mathrm{bp}$ ladder (Thermo Scientific). $C P$ is the positive control ( $P$. aeruginosa ATCC 27853), CN is the negative control (DNA free template), and lanes 1-4 show the specific DNA product of approximately 396 base pairs (bp) amplified from all retrieved multi-drug resistant (MDR) isolates. 


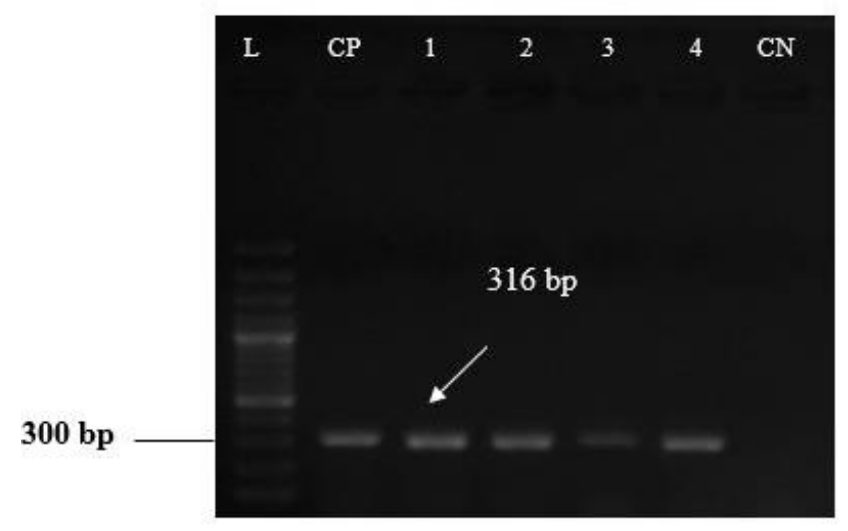

Figure 4. Electrophoretic pattern of primers targeting the mexA gene. $L$ refers to the $100 \mathrm{bp}$ molecular mass ladder (Thermo Scientific). CP is the positive control ( $P$. aeruginosa ATCC 27853), CN is the negative control (DNA free template), and lanes 1-4 show the specific DNA product of approximately 316 base pairs (bp) amplified from all retrieved multi-drug resistant (MDR) isolates.

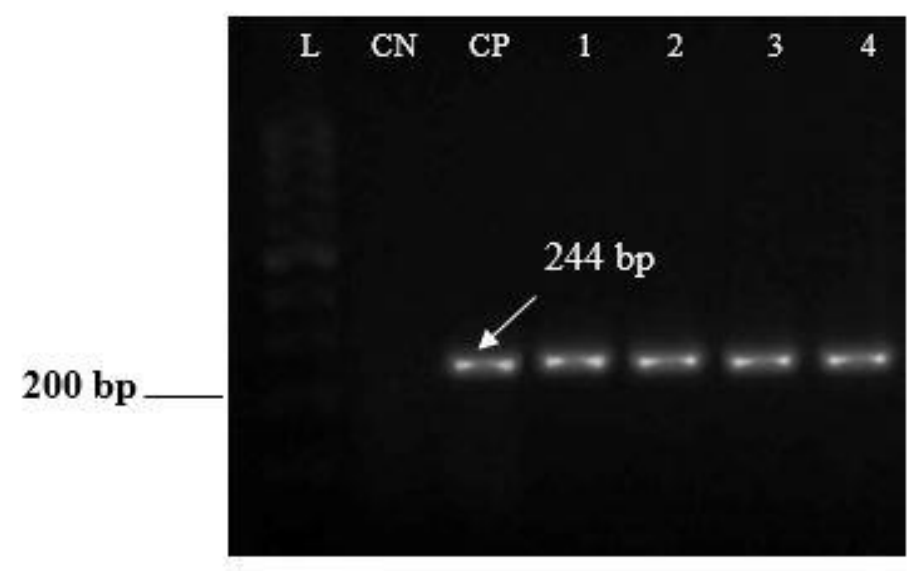

Figure 5. Electrophoretic pattern of primers targeting the mexB gene. $\mathrm{L}$ refers to the $100 \mathrm{bp}$ molecular mass ladder (Thermo Scientific). CP is the positive control (P. aeruginosa ATCC 27853), CN is the negative control (DNA free template), and lanes 1-4 show the specific DNA product of approximately 244 base pairs (bp) amplified from all retrieved multi-drug resistant (MDR) isolates.

Table. 5. Bactericidal activities, minimum inhibitory concentration (MIC), and minimum bactericidal concentration (MBC) of Origanum marjoram essential oil extract against four multi-drug resistant (MDR) isolates of $P$. aeruginosa.

\begin{tabular}{|c|c|c|c|c|c|c|c|c|c|c|c|c|}
\hline \multirow[t]{2}{*}{$\begin{array}{l}\text { Isolate } \\
\text { no. }\end{array}$} & \multirow[t]{2}{*}{$\begin{array}{l}\text { Inhibition zone } \\
\text { diameter }(\mathrm{mm})\end{array}$} & \multicolumn{9}{|c|}{$\begin{array}{l}\text { Different concentrations of } O \text {. marjoram essential oil } \\
\qquad\left(\mu \mathrm{g} \mathrm{ml}^{-1}\right)\end{array}$} & \multirow[t]{2}{*}{$\begin{array}{c}\mathrm{MIC} \\
\left(\mu g \mathrm{ml}^{-1}\right)\end{array}$} & \multirow[t]{2}{*}{$\begin{array}{c}\mathrm{MBC} \\
\left.(\mu \mathrm{g} \mathrm{m})^{-1}\right)\end{array}$} \\
\hline & & 512 & 256 & 128 & 64 & 32 & 16 & 8 & 4 & 2 & & \\
\hline 2 & $28.30 \pm 0.57$ & - & - & - & - & - & + & + & + & + & 16 & 32 \\
\hline 5 & $16.67 \pm 1.15$ & - & - & - & + & + & + & + & + & + & 64 & 128 \\
\hline 8 & $17.33 \pm 0.57$ & - & - & - & + & + & + & + & + & + & 64 & 128 \\
\hline 9 & $33 \pm 2$ & - & - & - & - & - & - & + & + & + & 8 & 16 \\
\hline
\end{tabular}

Data are presented as the means \pm SD $(n=3)$. 
range for optimum fish growth (Meade, 1989). The temperature values were slightly high $\left(29-31^{\circ} \mathrm{C}\right)$, thus favouring the occurrence of disease. Indeed, water temperature is a critical parameter for the optimal growth of various mesophilic bacteria and influences their occurrence in a cultured fish environment (Rheinheimer, 1992). Particularly in summer, higher water temperature leads to either decreased solubility of oxygen or increased metabolism of pond organisms and subsequent oxygen consumption (Noga, 2010). Tilapia can tolerate a rapid decrease in temperature better than a steady rise in temperature. Fish innate immunity might be delayed to equilibrate the temperature increase and thus accelerate the process of bacterial invasion (Meyers et al., 1994).

Further, relatively high values of unionized ammonia were recorded, suggesting the presence of organic matter compost and reflecting the poor sanitary conditions inside these farms. The threshold limit of unionized ammonia for most of the aquatic organisms was $0.1 \mathrm{mg} \mathrm{l}^{-1}$ (Santhosh \& Singh, 2007), and sub-lethal stressful effects are exerted with values between 0.1 and $0.3 \mathrm{mg} \mathrm{l}^{-1}$ (Robinette, 1976). The microbial water analyses revealed an increased microbial load and

Table. 6. Bactericidal activities, minimum inhibitory concentration (MIC), and minimum bactericidal concentration (MBC) of Origanum vulgare essential oils extract against four multi-drug resistant (MDR) isolates of $P$. aeruginosa

\begin{tabular}{|c|c|c|c|c|c|c|c|c|c|c|c|c|}
\hline \multirow[t]{2}{*}{$\begin{array}{l}\text { Isolate } \\
\text { no. }\end{array}$} & \multirow[t]{2}{*}{$\begin{array}{l}\text { Inhibition zone } \\
\text { diameter }(\mathrm{mm})\end{array}$} & \multicolumn{9}{|c|}{$\begin{array}{l}\text { Different concentrations of } O \text {. vulgare essential oil ( } \mu \mathrm{g} \\
\left.\qquad \mathrm{ml}^{-1}\right)\end{array}$} & \multirow[t]{2}{*}{$\begin{array}{c}\mathrm{MIC} \\
\left(\mu g \mathrm{ml}^{-1}\right)\end{array}$} & \multirow[t]{2}{*}{$\begin{array}{c}\mathrm{MBC} \\
\left(\mu \mathrm{g} \mathrm{ml} l^{-1}\right)\end{array}$} \\
\hline & & 512 & 256 & 128 & 64 & 32 & 16 & 8 & 4 & 2 & & \\
\hline 2 & $21.66 \pm 1.15$ & - & - & - & - & + & + & + & + & + & 32 & 64 \\
\hline 5 & $22 \pm 1$ & - & - & - & - & + & + & + & + & + & 32 & 64 \\
\hline 8 & $15.60 \pm 1.53$ & - & - & - & + & + & + & + & + & + & 64 & 128 \\
\hline 9 & $29 \pm 1.73$ & - & - & - & - & - & + & + & + & + & 16 & 32 \\
\hline
\end{tabular}

\section{A}

Origanum marjoram $\left(\mu \mathrm{g} \mathrm{ml}^{-1}\right)$

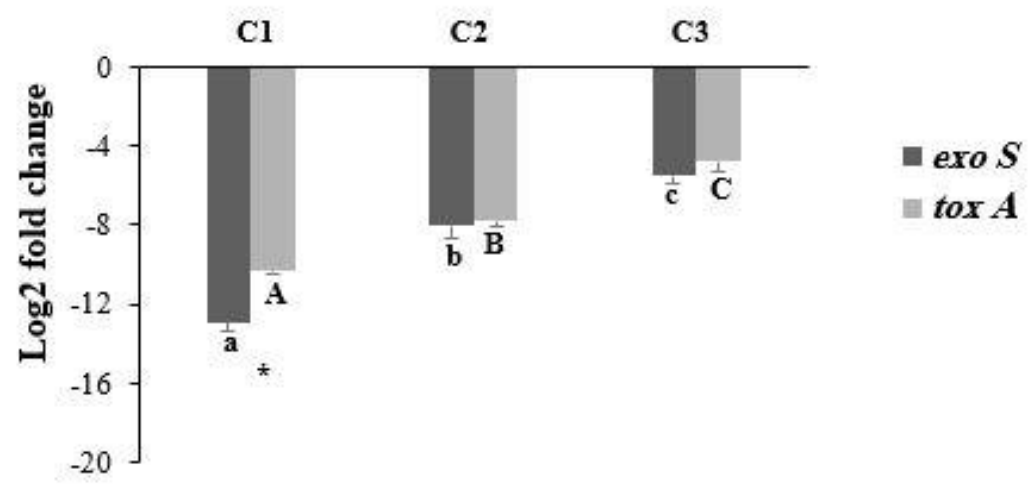

B Origanum vulgare $\left(\mu \mathrm{g} \mathrm{ml}^{-1}\right)$

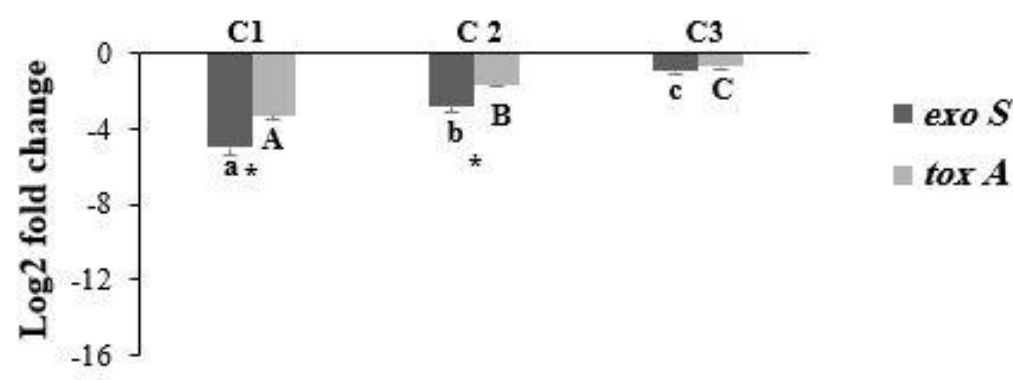

Figure 6. Log 2 fold change in the expression level of $P$. aeruginosa virulence genes (exoS and toxA) in response to three sub inhibitory concentrations ( $\mathrm{SICs}, \mu \mathrm{g} \mathrm{ml}^{-1}$ ) of (A) Origanum marjoram (6 $\left.\mathrm{g} \mathrm{ml}^{-1}, \mathrm{C} 1 ; 4 \mu \mathrm{g} \mathrm{ml}^{-1}, \mathrm{C} 2 ; 2 \mu \mathrm{g} \mathrm{ml}-1, \mathrm{C} 3\right)$ and (B) Origanum vulgare $\left(14 \mathrm{~m} \mathrm{ml}^{-1}, \mathrm{C} 1 ; 12 \mathrm{\mu g} \mathrm{ml}^{-1}, \mathrm{C} 2 ; 10 \mathrm{\mu g} \mathrm{ml}^{-1}, \mathrm{C} 3\right)$. All genes of interest were normalized to the expression of the regulator gene $o p r L$. Negative values represent downregulated genes in the presence of essential oils. Data are presented as the means \pm $\mathrm{SD}(\mathrm{n}=3)$. Different letters indicate significant changes in the expression level of the exoS gene (lowercase) or the toxA gene (capital), while asterisks indicate significant differences between the evaluated genes for each particular concentration (ANOVA; $\mathrm{P}<0.05)$. 
suggested possible faecal contamination. Specifically, the environmental stresses negatively affect fish homeostasis and thereby reduce their resistance to the pathogenic organisms (Small \& Bilodeau, 2005). The presence of bacteria in a large population may greatly affect susceptible fish, particularly in adverse environmental conditions. Bacteria are likely to appear in fish musculature when their concentration in water exceeds $5 \times 10^{4} \mathrm{CFU} \mathrm{ml}^{-1}$ (Buras, Duek \& Niv, 1985).

Regarding the clinical signs of the infected fish, most of the clinical findings were nearly similar to those observed by Eissa, El-Ghiet, Shaheen and Abbass (2010). The common signs of haemorrhagic septicaemia, ulcerative skins, gill necrosis, and fin rot have been reported in several fish species infected with $P$. aeruginosa (Shen et al., 2008; Austin et al., 2012). Several studies precisely elucidated bacterial pathogenesis and its negative effects on different organs, including the liver and kidney (Shayo, Mwita \& Hosea, 2012). Furthermore, concomitant deteriorations of the scale structure, such as lepidontal damage, chromatophore dispersion, circuli breakage, and scale loosening, have been reported in Channa punctata (freshwater murrel) experimentally challenged with $P$. aeruginosa (Saikia, Chattopadhyay, Banerjee \& Sarma, 2017). Such bacterial species harbor a variety of virulence factors that could increase their infectious severity. The pathogenesis of $P$. aeruginosa infections is considerable and complex, as manifested by the numerous toxins, extracellular enzymes and other virulence factors (Vasil, 1986).

The results of the bacteriological analysis revealed that $P$. aeruginosa was the only isolate retrieved from infected fish, in agreement with the findings of Roberts (2001). Several cases of $P$. aeruginosa infection were reported in some cultured $O$. niloticus in Kafr el-Sheikh, Behira, Menofya, and Sharkia (Hanna, El-Hady, Ahmed, Elmeadawy \& Kenwy, 2014). Similarly, Eissa et al. (2010) isolated different types of pseudomonads, namely, $P$. putida, $P$. aeruginosa, $P$. fluorescens and $P$. anguilliseptica from tilapia in the Qaroun and Wadi-ElRayan Lakes in Egypt. Most of the fish species are susceptible to Pseudomonas spp., which results in moderate to high economic losses (Somsiri \& Soontornvit, 2002).

Regarding the prevalence of $P$. aeruginosa in different internal organs, both the skin lesions and liver were the most abundantly infected organs, followed by the kidney and spleen, which was in agreement with the findings of Sakr and El-Rhman (2008) and Fadel et al. (2018). The present findings suggested that both the liver and kidney are the principal target organs of disease. The propensity of bacteria towards these tissues could be related to certain virulence factors encoded by bacteria, which promote their septicemic existence in the detoxification organ (liver) and a main hemobiotic organ (kidney).

In the present study, molecular typing of $P$. aeruginosa was performed using a set of primers targeting the oprL gene sequence, and the results revealed that all retrieved strains were positive, with a specific amplicon size of 504 bp (Matthijs et al., 2013). Additionally, there was homogeneity in the distinct banding patterns of all amplified isolates. The selected gene encodes both the $\mathrm{I}$ and $\mathrm{L}$ outer membrane lipoproteins of $P$. aeruginosa (Pirnay et al., 2002) is the superior for the detection of $P$. aeruginosa isolates (Lavenir, Jocktane, Laurent, Nazaret \& Cournoyer, 2007). Simultaneously, the molecular typing of virulence genes was performed for MDR isolates using different sets of primers targeting exoS and toxA gene sequences (Matar et al., 2002; Strateva, 2008), and the results revealed that all evaluated strains were positive with specific amplicon sizes of 504 and 396 bp, respectively. These results are compatible with those obtained by Benie, Dadie, Guessennd, Kouame and N'gbessoKouadio (2017), who confirmed the presence of exoS genes among 33 and 26 isolates of $P$. aeruginosa retrieved from fresh and smoked fish, respectively.

The exoS gene is critical for bacterial pathogenicity since it induces host tissue degeneration and apoptosis, accelerates bacterial cell adhesion and colonization and fortifies their dissemination (Mitov et al., 2010; Mesquita, Soares-Castro, Santos \& Mendez-Vilas, 2013; Arabestani, Rajabpour, Yousefi Mashouf, Alikhani \& Mousavi, 2015). The toxA gene is also a fundamental virulence tool because it activates bacterial enzymes, interferes with protein synthesis, and enhances the ability of the pathogen to destroy host tissues (Arabestani et al., 2015; Michalska \& Wolf, 2015).

Concerning antibiotic susceptibility, all retrieved isolates showed different sensitivity and resistance patterns to several commercial antimicrobial agents. The evaluated strains were entirely sensitive to streptomycin and highly resistant to erythromycin, florfenicol, and amoxicillin. Surprisingly, 4 out of 11 evaluated strains exhibited co-resistance to more than three antimicrobial agents and were defined as MDR strains. These results were similar to those obtained by Luczkiewicz, Kotlarska, Artichowicz, Tarasewicz and Fudala-Ksiazek (2015). The natural resistance of $P$. aeruginosa to different antibiotics is mainly attributed to the presence of the mex $\mathrm{A}$ and mex $\mathrm{B}$ genes among evaluated isolates, which in turn reduce the permeability of the bacterial cell wall to antibiotics (Li, Nikaido \& Poole, 1995). Alternatively, it could be attributed to the regular presence of antibiotics in the water of the sampling localities, as a result of agricultural or municipal drainages (Abdel-Aziz, Eissa, Hanna \& Okada, 2013). In the current study, the detection of both the mexA and mexB genes among the MDR isolates was investigated and revealed specific bands of 316 and $244 \mathrm{bp}$ in length, respectively, in agreement with the findings of Lister, Wolter and Hanson (2009).

The presence of MDR strains reveals the imperative need to identify appropriate antibiotics of plant origins. Herbal medication is currently flourishing 
and represents a new pharmacological trend in disease control that will hopefully combat the problems related to antibiotic resistance (Valladão, Gallani \& Pilarski, 2015). Although several studies have illustrated the potential bactericidal activity of oregano essential oils against several bacterial pathogens (Tiwari et al., 2009; Corduk, Sarica \& Yarim, 2013), little is known about their applicable uses in aquaculture, and no study has precisely explained their regulatory effect on some expressed virulence genes of pathogenic bacteria.

Regarding the potential activities of oregano essential oils against the four MDR isolates of $P$. aeruginosa, our findings were similar to those reported by Deans and Svoboda (1990) and Mabrok and Wahdan (2018). In the present study, Origanum extracts displayed variant and dose-dependent bactericidal activities against MDR isolates of $P$. aeruginosa. The bactericidal activity in samples treated with $O$. marjoram was higher than that in samples treated with o. vulgare. Both plant extracts harbour several components with antibacterial and antifungal properties (a- and y-terpinene, sabinene, linalool, cissabinene hydrate, eugenol, and carvacrol) (Ezzeddine, Abdelkefi, Aissa \& Chaabouni, 2001). These obvious antimicrobial activity could be attributed to carvacrol and thymol, the two main active components that can disintegrate the outer membrane of bacteria, increase their permeability and thereby induce cell necrosis (Helander et al., 1998; Chopra, Nayar \& Chopra, 2006). A key in the current study was the high efficacy of $O$. marjoram and $O$. vulgare at high SICs, at which the expression levels of the exoS and toxA genes were reduced by up to 12 -fold when compared to those of the untreated control. These results lend credence to the reports of El-Hamid et al. (2019), who noticed marked downregulation in five virulence genes of MDR isolates of Pasteurella multocida following treatment with $O$. marjoram extract. Overall, the present study provides promising insights into the potential uses of $O$. marjoram and $O$. vulgare extracts for the treatment of MDR isolates of Pseudomonas aeruginosa virulent strains. However, there is an urgent need for itemized immunological and molecular studies to publicize the application of these results in fish production sectors as a precautionary measure.

\section{Conclusions}

The pathogenicity and environmental associated risks of $P$. aeruginosa infection have been clarified based on the occurrence of bacteria in both fish and pond water and through the detection of some virulence and antibiotic resistance genes. Additionally, the current data reflect the possible use of a natural antimicrobial compound of herbal origin as a fish farming control strategy. Finally, yet importantly, the present study first investigated the regulatory effects of both $O$. marjoram and $O$. vulgare extracts on select virulence genes of $P$. aeruginosa, revealing novel findings that encourage their use as antibiotic surrogates to control MDR pseudomoniasis cases.

\section{Acknowledgements}

The authors declare that they have no significant competing financial, professional or personal interests that may have influenced this study.

\section{References}

Abdel-Aziz, M., Eissa, A. E., Hanna, M., \& Okada, M. A. (2013). Identifying some pathogenic Vibrio/Photobacterium species during mass mortalities of cultured gilthead seabream (Sparus aurata) and European seabass (Dicentrarchus labrax) from some Egyptian coastal provinces. International Journal of Veterinary Science and Medicine, 1 (2), 87-95.

https://doi.org/10.1016/j.ijvsm.2013.10.004

Abdullahi, S., Abolude, D., \& Ega, R. (2001). Nutrient quality of four oven dried freshwater catfish species in Northern Nigeria. J. Tropical Biosciences, 1 (1), 70-76.

Alqarni, B., Colley, B., Klebensberger, J., McDougald, D., \& Rice, S. A. (2016). Expression stability of 13 housekeeping genes during carbon starvation of Pseudomonas aeruginosa. Journal of Microbiological Methods, 127, 182-187. https://doi.org/10.1016/j.mimet.2016.06.008

APHA, A. P. H. A. (2005). Standard Methods for the Examination of Water and Wastewater (21st Ed.), American Public Health Association, Washington, DC.USA.

Arabestani, M. R., Rajabpour, M., Yousefi Mashouf, R., Alikhani, M. Y., \& Mousavi, S. M. (2015). Expression of efflux pump MexAB-OprM and OprD of Pseudomonas aeruginosa strains isolated from clinical samples using qRT-PCR. Archives of Iranian Medicine, 18 (2), 102-108. http://eprints.umsha.ac.ir/id/eprint/1684

Austin, B., \& Austin, D. A. (2012). Bacterial Fish Pathogens: Springer.https://doi.org/10.1007/978-94-007-4884-2

Bagamboula, C., Uyttendaele, M., \& Debevere, J. (2004). Inhibitory effect of thyme and basil essential oils, carvacrol, thymol, estragol, linalool and p-cymene towards Shigella sonnei and $S$. flexneri. Food Microbiology, 21 (1), 33-42.

https://doi.org/10.1016/S0740-0020(03)00046-7

Benie, C., Nathalie, G., \& Adjéhi, D. (2017). Prevalence and antibiotic resistance of Pseudomonas aeruginosa isolated from bovine meat, fresh fish and smoked fish. Arch Clin Microbiol, 8, 3. https://doi.org/10.4172/19898436.100040.

Benie, C. K. D., Dadie, A., Guessennd, N., Kouame, N. D., \& N'gbesso-Kouadio, N. A. (2017). Molecular identification and virulence factors of Pseudomonas aeruginosa strains isolated from animal products. J Bacteriol, 4 (3). https://doi.org/10.15406/jbmoa.2017.04.00094.

Bertrand-Harb, C., Ivanova, I., Dalgalarrondo, M., \& Haertllé, T. (2003). Evolution of $\beta$-lactoglobulin and $\alpha$-lactalbumin content during yoghurt fermentation. International Dairy Journal, 13 (1), 39-45. https://doi.org/10.1016/S0958-6946(02)00140-1.

Buras, N., Duek, L., \& Niv, S. (1985). Reactions of fish to microorganisms in wastewater. Applied and Environmental Microbiology, 50 (4), 989-995. http://aem.asm.org/ 
Busatta, C., Vidal, R., Popiolski, A., Mossi, A., Dariva, C., Rodrigues, M., . . . Cansian, R. (2008). Application of Origanum majorana L. essential oil as an antimicrobial agent in sausage. Food Microbiology, 25 (1), 207-211. https://doi.org/10.1016/j.fm.2007.07.003.

Castanon, J. (2007). History of the use of antibiotic as growth promoters in European poultry feeds. Poultry Science, 86 (11), 2466-2471. https://doi.org/10.3382/ps.200700249.

Chopra, R., Nayar, S., \& Chopra, I. (2006). Glossary of Indian medicinal plants, national institute of science communication and information resources. New Delhi: CSIR. https://trove.nla.gov.au/version/20133153.

CLSI. (2008). Performance standards for antimicrobial disc and dilution susceptibility tests for bacteria isolated from animals, 3rd ed. Wayne: Clinical and Laboratory Standards

Institute.https://clsi.org/media/2321/vet08ed4_sample .pdf.

Corduk, M., Sarica, S., \& Yarim, G. (2013). Effects of oregano or red pepper essential oil supplementation to diets for broiler chicks with delayed feeding after hatching. 1. Performance and microbial population. Journal of Applied Poultry Research, 22 (4), 738-749. https://doi.org/10.3382/japr.2012-00672.

Deans, S., \& Svoboda, K. P. (1990). The antimicrobial properties of marjoram (Origanum majorana L.) volatile oil. Flavour and Fragrance Journal, 5 (3), 187-190. https://doi.org/10.1002/ffj.2730050311.

Dumas, J.-L., Van Delden, C., Perron, K., \& Köhler, T. (2006). Analysis of antibiotic resistance gene expression in Pseudomonas aeruginosa by quantitative real-time-PCR. FEMS Microbiology letters, 254 (2), 217-225. https://doi.org/10.1111/j.1574-6968.2005.00008.x.

Eissa, N., El-Ghiet, E. A., Shaheen, A., \& Abbass, A. (2010). Characterization of Pseudomonas species isolated from tilapia "Oreochromis niloticus" in Qaroun and Wadi-ElRayan lakes, Egypt. Global Veterinaria, 5 (2), 116-121.

El-Hamid, M. I. A., El-Sayed, M., Ali, A. R., Abdallah, H., Arnaout, M. I., \& El-mowalid, G. A. (2019). Marjoram extract down-regulates the expression of Pasteurella multocida adhesion, colonization and toxin genes: A potential mechanism for its antimicrobial activity. Comparative Immunology, Microbiology and Infectious Diseases, 62, 101-108. https://doi.org/10.1016/j.cimid.2018.11.007.

Ezzeddine, N. B. H.-B., Abdelkefi, M., Aissa, R. B., \& Chaabouni, M. (2001). Antibacterial screening of Origanum majorana L. oil from Tunisia. Journal of Essential Oil Research, 13 (4), 295-297. https://doi.org/10.1080/10412905.2001.9699698.

Fadel, A., Mabrok, M., \& Aly, S. (2018). Epizootics of Pseudomonas anguilliseptica among cultured seabream (Sparus aurata) populations: Control and treatment strategies. Microbial Pathogenesis, 121, 18.https://doi.org/10.1016/j.micpath.2018.04.021.

FAO (2018). The State of World Fisheries and Aquaculture 2018- Meeting the sustainable development goals. Rome. Licence: CC BY-NC-SA 3.0 IGO; 2018. https://doi.org/10.18356/8d6ea4b6-en

Handzlik, J., Matys, A., \& Kieć-Kononowicz, K. (2013). Recent advances in multi-drug resistance (MDR) efflux pump inhibitors of Gram-positive bacteria $S$. aureus. Antibiotics, 2 (1), 28-45.

https://doi.org/10.3390/antibiotics2010028.
Hanna, M., El-Hady, M., Ahmed, H., Elmeadawy, S., \& Kenwy, A. (2014). A contribution on Pseudomonas aeruginosa infection in African Catfish (Clarias garipinus). Research Journal of Pharmaceutical Biological and Chemical Sciences, 5, 175-588.

https://www.academia.edu/12284523/A.

Helander, I. M., Alakomi, H.-L., Latva-Kala, K., MattilaSandholm, T., Pol, I., Smid, E. J., ... von Wright, A. (1998). Characterization of the action of selected essential oil components on Gram-negative bacteria. Journal of agricultural and food chemistry, 46 (9), 3590-3595. https://doi.org/10.1021/jf980154m.

Hwang, Y. S., Bang, S. J., Kang, T. Y., Choi, J. H., Jung, S. M., Kang, I. S., ... \& Choi, S. (2019). The dietary effect of medicinal herbs extract and multiple probiotics mixture on the growth performance, innate immune response and antibacterial activity of Nile tilapia Oreochromis niloticus. 한국어병학회지, 32(1), 9-20.

Ismail, M., Wahdan, A., Yusuf, M., S, Metwally, E., \& Mabrok, M. Effect of dietary supplementation with a synbiotic (Lacto Forte) on growth performance, haematological and histological profiles, the innate immune response and resistance to bacterial disease in Oreochromis niloticus. Aquaculture Research. https://doi.org/10.1111/are.14212.

Jorgensen, J. H., Hindler, J. F., Reller, L. B., \& Weinstein, M. P. (2007). New consensus guidelines from the Clinical and Laboratory Standards Institute for antimicrobial susceptibility testing of infrequently isolated or fastidious bacteria. Clinical Infectious Diseases, 44 (2), 280-286. https://doi.org/10.1086/510431.

Khattab, M., Nour, M., \& ElSheshtawy, N. (2015). Genetic identification of Pseudomonas aeruginosa virulence genes among different isolates. J Microb Biochem Technol, 7 (5), 274-277. https://doi.org/10.4172/19485948.1000224

Kumaran, S., Deivasigamani, B., Alagappan, K., Sakthivel, M., \& Prasad, S. G. (2010). Isolation and characterization of Pseudomonas sp. KUMS3 from Asian seabass (Lates calcarifer) with fin rot. World Journal of Microbiology and Biotechnology, 26 (2), 359-363. https://doi.org/10.1007/s11274-009-0158-4.

Lambert, R., Skandamis, P. N., Coote, P. J., \& Nychas, G. J. (2001). A study of the minimum inhibitory concentration and mode of action of oregano essential oil, thymol and carvacrol. Journal of Applied Microbiology, 91 (3), 453462. https://doi.org/10.1046/j.1365-2672.2001.01428.x.

Lavenir, R., Jocktane, D., Laurent, F., Nazaret, S., \& Cournoyer, B. (2007). Improved reliability of Pseudomonas aeruginosa PCR detection by the use of the speciesspecific ecfX gene target. Journal of Microbiological Methods, 70 (1), 20-29.

https://doi.org/10.1016/j.mimet.2007.03.008.

Li, X.-Z., Nikaido, H., \& Poole, K. (1995). Role of mexA-mexBoprM in antibiotic efflux in Pseudomonas aeruginosa. Antimicrobial Agents and Chemotherapy, 39 (9), 19481953. https://doi.org/10.1128/AAC.39.9.1948.

Lister, P. D., Wolter, D. J., \& Hanson, N. D. (2009). Antibacterialresistant Pseudomonas aeruginosa: clinical impact and complex regulation of chromosomally encoded resistance mechanisms. Clinical Microbiology Reviews, 22 (4), 582-610. https://doi.org/10.1128/CMR.0004009. 
Livak, K. J., \& Schmittgen, T. D. (2001). Analysis of relative gene expression data using real-time quantitative PCR and the 2- $\triangle \Delta C T$ method. Methods, 25 (4), 402-408. https://doi.org/10.1006/meth.2001.1262.

Luczkiewicz, A., Kotlarska, E., Artichowicz, W., Tarasewicz, K., \& Fudala-Ksiazek, S. (2015). Antimicrobial resistance of Pseudomonas spp. isolated from wastewater and wastewater-impacted marine coastal zone. Environmental Science and Pollution Research, 22 (24), 19823-19834. https://doi.org/10.1007/s11356-0155098-y.

Mabrok, M. A. E., \& Wahdan, A. (2018). The immune modulatory effect of oregano (Origanum vulgare L.) essential oil on Tilapia zillii following intraperitoneal infection with Vibrio anguillarum. Aquaculture International, 1-14. https://doi.org/10.1007/s10499018-0274-y.

Mac Faddin, J. F. (1985). Media for isolation-cultivationidentification-maintenance of medical bacteria: Williams \& Wilkins.

Matar, G. M., Ramlawi, F., Hijazi, N., Khneisser, I., \& Abdelnoor, A. M. (2002). Transcription levels of pseudomonas aeruginosa exotoxin A gene and severity of symptoms in patients with otitis externa. Current Microbiology, 45 (5), 350-354. https://doi.org/10.1007/s00284-002-3703-z.

Matthijs, S., Coorevits, A., Gebrekidan, T. T., Tricot, C., Vander Wauven, C., Pirnay, J.-P., . . . Cornelis, P. (2013). Evaluation of oprl and oprL genes as molecular markers for the genus Pseudomonas and their use in studying the biodiversity of a small Belgian River. Research in Microbiology, 164 (3), 254-261. https://doi.org/10.1016/j.resmic.2012.12.001.

Meade, J. W. (1989). Aquaculture Management. Chapman and Hall; 175pp. https://doi.org/10.1007/978-1-4615-64706.

Mesquita, C. S., Soares-Castro, P., Santos, P. M., \& MendezVilas, A. (2013). Pseudomonas aeruginosa: phenotypic flexibility and antimicrobial resistance. Microbial pathogens and strategies for combating them: science, technology and education (Vol. 1, pp. 650-665): Formatex Research Center.

Meyers, T., Short, S., Lipson, K., Batts, W., Winton, J., Wilcock, J., \& Brown, E. (1994). Association of viral hemorrhagic septicemia virus with epizootic hemorrhages of the skin in Pacific herring Clupea harengus pallasi from Prince William Sound and Kodiak Island, Alaska, USA. Diseases of Aquatic Organisms, 19 (1), 27-37. https://doi.org/10.3354/dao019027.

Michalska, M., \& Wolf, P. (2015). Pseudomonas Exotoxin A: optimized by evolution for effective killing. Frontiers in Microbiology, 6 , https://doi.org/10.3389/fmicb.2015.00963.

Mitov, I., Strateva, T., \& Markova, B. (2010). Prevalence of virulence genes among Bulgarian nosocomial and cystic fibrosis isolates of Pseudomonas aeruginosa. Brazilian Journal of Microbiology, 41 (3), 588-595. https://doi.org/10.1590/S1517-83822010000300008.

Noga, E. J. (2010). Pharmacopoeia. Fish disease: Diagnosis and Treatment, 375-420. https://doi.org/10.1002/9781118786758.ch17.

Omar, A. A. E.-D., Moustafa, E. M., Abo-Remela, E. M., \& Zayed, M. M. (2017). Prevalence, molecular characterization, pathogenecity and antimicrobial susceptibility of Pseudomonas fluorescens isolated from Oreochromis niloticus. Life Science Journal, 14 (8).
Pirnay, J. P., De Vos, D., Cochez, C., Bilocq, F., Vanderkelen, A., Zizi, M., . . . Cornelis, P. (2002). Pseudomonas aeruginosa displays an epidemic population structure. Environmental Microbiology, 4 (12), 898911.https://doi.org/10.1046/j.1462-2920.2002.00321.x.

Rheinheimer, G. (1992). The influence of environmental factors on the development of microorganisms. Aquatic Microbiology, 4, 111-147.

Roberts, R. J. (2001). Fish pathology" 3rd Edition, 2001. Bailliere tindall, London England. https://trove.nla.gov.au/work/32689473.

Robinette, H. R. (1976). Effect of selected sublethal levels of ammonia on the growth of channel catfish (Ictalurus punctatus). The Progressive Fish-Culturist, 38 (1), 26-29. https://doi.org/10.1577/15488659(1976)38[26:EOSSLO]2.0.CO;2.

Saikia, D. J., Chattopadhyay, P., Banerjee, G., \& Sarma, D. (2017). Time and dose dependent effect of Pseudomonas aeruginosa infection on the scales of Channa punctata (Bloch) through light and electron microscopy. Turkish Journal of Fisheries and Aquatic Sciences, 17 (5), 871-876. https://doi.org/10.4194/13032712-v17_5_03.

Sakr, S. F., \& El-Rhman, A. M. A. (2008). Contribution on Pseudomonas septicemia caused by Pseudomonas anguilliseptica in cultured Oreochromis niloticus. Paper presented at the 8 th International symposium on tilapia in aquaculture 2008.

https://cals.arizona.edu/azaqua/ista/ISTA8/FinalPapers /12/3\%20Fish\%20Disease\%20Bacterial/Salh\%201/Saleh \%20Sakr\%20photos\%2011.doc.

Santhosh, B., \& Singh, N. P. (2007). Guidelines for water quality management for fish culture in Tripura, ICAR Research Complex for NEH Region, Tripura Center, Publication no. 29

Schmidt, E., Wanner, J., Höferl, M., Jirovetz, L., Buchbauer, G., Gochev, V., ... Geissler, M. (2012). Chemical composition, olfactory analysis and antibacterial activity of Thymus vulgaris chemotypes geraniol, 4-thujanol/terpinen-4-ol, thymol and linalool cultivated in southern France. Natural Product Communications, 7(8), $1934578 \times 1200700833$. https://doi.org/10.1177/1934578X1200700833.

Senapin, S., Shyam, K.U., Meemetta, W., Rattanarojpong, T., Dong, H.T. (2018). Inapparent infection cases of tilapia lake virus (TiLV) in farmed tilapia. Aquaculture, 487, 5155. https://doi.org/10.1016/j. aquaculture.2018.01.007

Sharma, S., \& Srivastava, P. (2016). Resistance of antimicrobial in Pseudomonas aeruginosa. Int J Curr Microbiol App Sci, 5 (3), 121-128.

https://doi.org/10.20546/ijcmas.2016.503.017.

Shayo, S., Mwita, C., \& Hosea, K. (2012). Virulence of Pseudomonas and Aeromonas bacteria recovered from Oreochromis niloticus (Perege) from Mtera hydropower Dam; Tanzania. Ann. Biol. Res, 3 (11), 5157-5161. http://scholarsresearchlibrary.com/archive.html.

Shen, J., Yu, X., Pan, X., Xu, W., Yin, W., \& Cao, Z. (2008). Isolation and identification of pseudomonas pathogen from cultured Pseudosciaena crocea. Mar Fish Res, 29, 16.

Small, B. C., \& Bilodeau, A. L. (2005). Effects of cortisol and stress on channel catfish (Ictalurus punctatus) pathogen susceptibility and lysozyme activity following exposure to Edwardsiella ictaluri. General and Comparative Endocrinology, 142 (1-2), 256-262. 
https://doi.org/10.1016/j.ygcen.2004.12.004

Somsiri, T., \& Soontornvit, S. (2002). Bacterial diseases of cultured tiger frog (Rana tigerina). Diseases in Asian Aquaculture IV, Fish Health Section, Asian Fisheries Society, Manila.

Strateva, T. (2008). Microbiological and molecular-genetic investigations on resistance mechanisms and virulence factors in clinical strains of Pseudomonas aeruginosa. Medical Univ of Sofia, Bulgaria.

Tiwari, B. K., Valdramidis, V. P., O'Donnell, C. P., Muthukumarappan, K., Bourke, P., \& Cullen, P. (2009). Application of natural antimicrobials for food preservation. Journal of Agricultural and Food Chemistry, 57(14), 5987-6000. https://doi.org/10.1021/jf900668n.

Valladão, G., Gallani, S., \& Pilarski, F. (2015). Phytotherapy as an alternative for treating fish disease. Journal of
Veterinary Pharmacology and Therapeutics, 38 (5), 417 428. https://doi.org/10.1111/jvp.12202.

Vasil, M. L. (1986). Pseudomonas aeruginosa: biology, mechanisms of virulence, epidemiology. The Journal of Pediatrics, 108 (5), 800-805.

https://doi.org/10.1016/S0022-3476(86)80748-X.

Wienkötter, N., Begrow, F., Kinzinger, U., Schierstedt, D., \& Verspohl, E. (2007). The effect of thyme extract on $\beta 2$ receptors and mucociliary clearance. Planta Medica, 73 (07), 629-635. https://doi.org/10.1055/s-2007-981535.

Xavier, D. E., Picão, R. C., Girardello, R., Fehlberg, L. C., \& Gales, A. C. (2010). Efflux pumps expression and its association with porin down-regulation and $\beta$-lactamase production among Pseudomonas aeruginosa causing blood stream infections in Brazil. BMC Microbiology, 10 (1), 217. https://doi.org/10.1186/1471-2180-10-217. 